\title{
Shear Bond Strength of Hydroxyapatite Liner to Composite Resin: Effect of Dentin Bonding Agents
}

\author{
Shiva Mishaeel ${ }^{1}$ and Amir H Namazi ${ }^{2 *}$ \\ ${ }^{1}$ Department of Operative Dentistry, Islamic Azad University of Medical Sciences, Iran \\ ${ }^{2}$ Department of Restorative, UCLA School of Dentistry, USA
}

Submission: February 13, 2017; Published: May 31, 2018

*Corresponding author: Amir H Namazi, Department of Restorative, UCLA School of Dentistry, Los Angeles, USA, Tel: 3106004004;

Email: amirhsnam@gmail.com

\begin{abstract}
Introduction: Liners and bases which are applied beneath the composite restorations should have acceptable bond strength with composite resin to reduce the microleakage.
\end{abstract}

Objective: The aim of this study was to determine the effect of two current dentin bonding agents on shear bond strength of Lime-Lite to light cure composite resin.

Material and Methods: In this experimental study, 30 cylindrical specimens of hydroxyapatite containing liner with $4 \mathrm{~mm}$ diameter and $8 \mathrm{~mm}$ height and 30 cylindrical specimens of composite resin with $5 \mathrm{~mm}$ diameter and $5 \mathrm{~mm}$ height were prepared according to ISO-11405. The specimens were divided in three groups of 10 and one of the three adhesives (Den TASTIC, Single bond, bond) were applied for bonding between composite resin and liner according to their manufacture's instruction. Specimens were kept in 100\% humidity for 24 hours. Shear bond strength test was done at a crosshead speed of $1 \mathrm{~mm} / \mathrm{min}$ by a universal testing machine. Data were analyzed by ANOVA and POST HOC TUKEY HSD.

Results: Mean shear bond strength in Mpa were as follows: Den TASTIC: $9.94 \pm 3.63$, Single bond: $12.79 \pm 2.92$ and bond: $15.28 \pm 4.11$. Statistical results showed that the shear bond strength of group three was significantly higher than group one. $(\mathrm{P}<0.05)$ There were no significant differences between group one $\&$ two and group two $\&$ three. ( $p>0.05)$

Conclusions: Type of adhesive systems had effect on shear bond strength of hydroxyapatite containing liner to composite resin.

Keywords: Liners; Hydroxyapatite containing liners; Shear bond strength; Composite resin; Dentin bonding agents

\section{Introduction}

The Integrity of a restoration is very important in its long term durability. In a deep cavity which has lost significant amount of dentin and is decided to restore with composite resin there are some concerns about polymerization shrinkage, bonding of composite resin and prevention of further microleakage [1,2]. In these situations there is need to place a suitable liner or base to overcome the mentioned problems.

There are different kinds of bases with various chemical compositions and mechanical properties which can be applied on cavity floor prior to composite resin placement. Shear bond strength of liners and bases to composite resin will have some benefits.

Nowadays the most common materials that are used as liner and base under the composite restorations are glass ionomer cements [1]. Glass ionomer is delivered in the form of powder and liquid, its preparation is hard and it might contact the walls of the cavity during its insertion and consequently contaminate the bond surface which is going to bond with composite resin $[3,4]$. Therefore, if it could be replaced by a material with acceptable shear bond strength, easier application and less technique sensitivity it will be promising.

In recent years some materials have been introduced to the market with some advantages like easy application and special chemical composition. Lime-Lite is a new resin-based material that could be applied as a liner and base, according to the manufacturer. The material contains Hydroxy Apatite (HA) and releases hydroxyl, fluoride, and calcium. It is radiopaque as glass ionomer which helps to distinguish it from dental caries [5]. Unfortunately, there is little evidence regarding the properties of this new material. There is a research about the compressive strength of this material with and without application of adhesives [6] but researches on glass ionomer is good guidance to do the study on this new material [7-10]. 
The aim of this experimental study was to evaluate the shear bond strength of lime lite to composite resin with different adhesive systems.

\section{Method and Materials}

This study was done according to ISO-11405 for shear bond strength [11].

\section{Samples preparation}

Composite resin samples: Thirty samples of composite resin (Filtek Z250, color A2, 3MESPE, USA) were prepared in plastic mold with $5 \mathrm{~mm}$ diameter and $5 \mathrm{~mm}$ height. Composite resin was inserted in the mold in $2 \mathrm{~mm}$ layers and each layer was cured with coltolux2.5 (Coltene, Switzerland) with a beam of $400 \mathrm{mw} /$ $\mathrm{cm}^{2}$, for 40 seconds and then for 60 seconds after removing the samples from the mold [12]. Polishing of composite samples were done by polishing disks (Esthetix, Dentsply, USA) from coarse to fine particle sizes. Each disk was used 10 seconds on each sample [13]. After polishing, the samples were rinsed and dried carefully by air spray.

Liner samples: To prepare thirty samples of Lime-Lite (Pulpdent, USA) a two-piece stainless steel cylindrical mold with a $4 \mathrm{~mm}$ diameter and $8 \mathrm{~mm}$ height was used. Lime-Lite was injected by syringe into the mold in $0.5 \mathrm{~mm}$ layers; each layer was cured for 30 seconds according to the manufacture's instruction under the mention conditions [5]. After removing the samples, curing was performed from different sides for 30 seconds.

All the samples of two groups were maintained in humid condition before application of adhesive. Samples of Lime-Lite were divided into three groups of ten randomly for application of adhesive systems as follows:

a) Group I: The surface of Lime-Lite was etched with Phosphoric acid 38\% (Etch-Rite, pulpdent, USA) for 15 seconds according to the manufacture's instruction. After rinsing for 20 seconds drying was done with a cotton pellet [5]. Two drops of Dent TASTIC (Pulpdent, USA) was well mixed and applied with a brush on the surface of Lime-Lite according to the manufacture's instruction [5], then the sample was placed on the surface of composite resin sample surface and was cured from different sides for ten seconds, total of 60 seconds.

b) Group II: The etching step was performed as in the first group, then the adhesive, Singlebond (3MESPE, USA), a totaletch two steps single bottle adhesive was applied on prepared surface of Lime-Lite samples according to manufacturer's instruction and cured same as group1.

c) Group III: The self-etch adhesive, (Kuraray, Japan) a self-etch one-step adhesive system, was used; Adhesive was applied according to the manufacturer's instruction with the brush on Lime-Lite surface, then it was dried by air pressure for 5 seconds and after being placed on the composite surface, the curing was done like before [14].

The samples were kept in the $37^{\circ} \mathrm{C}$ with $100 \%$ humidity conditions for 24 hours. Shear bond strength of the samples were examined in a universal testing machine (Zwick Roell20, Germany) and the force was applied to the interface of Lime-Lite and composite resin with $1 \mathrm{~m} / \mathrm{min}$ speed until the failure happened and bond strength was calculated by Force/Area formula in Mpa [11]. Finally the samples were evaluated for the failure type (adhesive, cohesive, mixed) with 30 magnifications.

\section{Results}

In this experimental research, the effects of three adhesive systems, Den TASTIC (Pulpdent, USA), Single bond (3MESPE, USA) and clearfils $^{3}$ (Kuraray, Japan) were assessed on the shear bond strength of the Lime-Lite to composite resin.

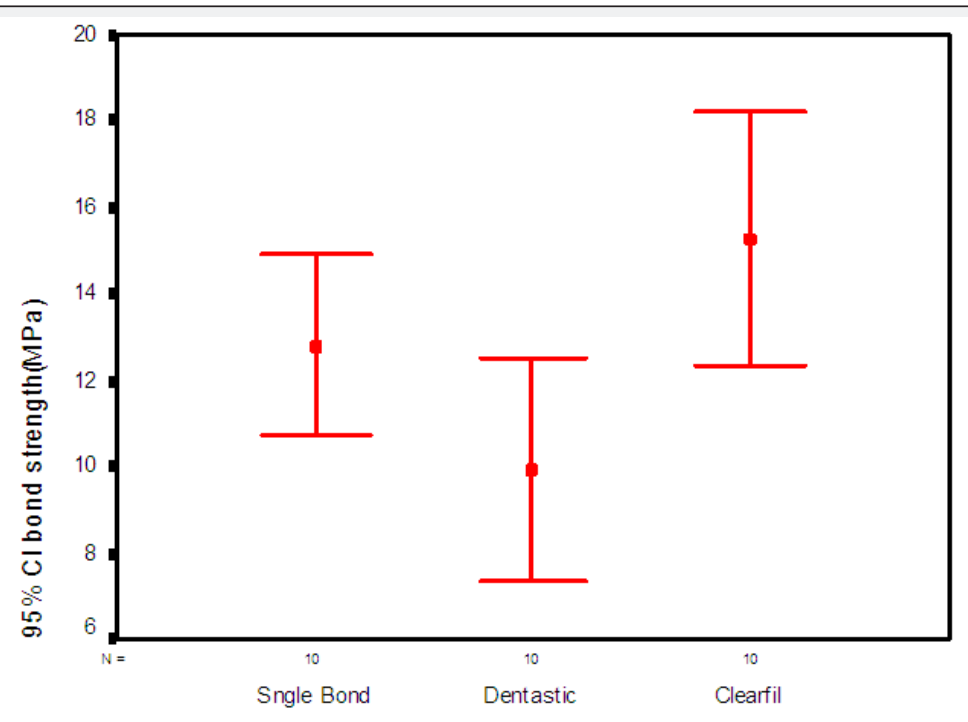

MATERIAL

Figure 1 


\section{Advances in Dentistry \& Oral Health}

Table 1: Mean of shear bond strength in groups.

\begin{tabular}{|c|c|c|c|}
\hline Material & Lot & Manufacturer & Components \\
\hline Lime-Lite & & PULPDENT, USA & $\begin{array}{l}\text { Hidroxyapatite, Uretandimethacrylate, } \\
\text { Fluoride, Sulfate barium Photo initiator }\end{array}$ \\
\hline Dent TASTIC & 52459 & PULPDENT, USA & Hydrophilic resin، PMGDM، Acetone \\
\hline Single bond & $6 \mathrm{JH}$ & 3MESPE, USA & $\begin{array}{c}\text { Ethanol, Water، HEMA،BISGMA , } \\
\text { Dimethacrylate }\end{array}$ \\
\hline clearfils $^{3}$ bond & $00085 \mathrm{~A}$ & KURARAY, JAPAN & $\begin{array}{l}\text { MDP,BISGMA ,HEMA‘Hydrophobic } \\
\text { Dimethacrylate ,Water ,Ethilalcohol, } \\
\text { Camphorquinone }\end{array}$ \\
\hline CompositeZ250 & 2010-04 & 3MESPE, USA & $\begin{array}{c}\text { BISGMA,UDMA,BISEMA, FillerZirconia/ } \\
\text { Silica }\end{array}$ \\
\hline
\end{tabular}

\begin{tabular}{|c|c|c|c|}
\hline Group & N & $\begin{array}{c}\text { Mean, } \\
\text { Std. Deviation }\end{array}$ & Std. Error \\
\hline $\begin{array}{c}\text { CompositeZ250- DenTASTIC } \\
\text { Lime-Lite }\end{array}$ & 10 & $3.63 \pm 9.94$ & 1.14 \\
\hline $\begin{array}{c}\text { CompositeZ250 Single bond } \\
\text { Lime-Lite }\end{array}$ & 10 & $2.92 \pm 12.79$ & 0.92 \\
\hline $\begin{array}{c}\text { CompositeZ250- DenTASTIC } \\
\text { Lime-Lite }\end{array}$ & 10 & $4.11 \pm 15.28$ & 1.3 \\
\hline
\end{tabular}

Table 1 shows the mean of shear bond strength of the three groups. The Dent TASTIC group had the lowest and clearfils $^{3}$ bond had the highest shear bond strength. Figure 1 shows the mean and the standard deviation of three groups with $95 \%$ confidence interval.

The ANOVA showed that the adhesives under surveillance have significant effects on the rate of the shear bond strength.
$(\mathrm{P}<0 / 05)$. The testing results of Post Hoc Tukey HSD showed that the application of clearfils $^{3}$ bond adhesive is significantly increases the shear bond strength of composite and Lime-Lite compared with the recommended Den TASTIC adhesive of the Lime-Lite manufacturer. $(\mathrm{P}<0 / 05)$ But, there is no significant difference for increment of the shear bond strength between the application of Single bond and Den TASTIC; and Single bond and clearfils $^{3}$ bond, too. $(\mathrm{P}>0 / 05)$ (Table 2).

Table 2

\begin{tabular}{|c|c|c|c|c|c|c|c|c|}
\hline & \multirow{2}{*}{} & \multirow{2}{*}{ Nean } & \multirow{2}{*}{$\begin{array}{c}\text { Std. } \\
\text { Deviation }\end{array}$} & \multirow{2}{*}{ Std. Error } & \multicolumn{2}{|c|}{$\mathbf{9 5 \% \text { Confidence Interval for Mean }}$} & \multicolumn{2}{|c|}{ Bond strength(MPa) } \\
\cline { 6 - 10 } & & & & Lower Bound & Upper Bound & Minimum & Maximum \\
\hline Single Bond & 10 & 12.7981 & 2.92035 & 0.9235 & 10.709 & 14.8872 & 9.37 & 18.69 \\
\hline Dentastic & 10 & 9.9471 & 3.63613 & 1.14985 & 7.346 & 12.5483 & 5.34 & 15.82 \\
\hline Clearfil & 10 & 15.2879 & 4.11327 & 1.30073 & 12.3454 & 18.2304 & 10.27 & 21.55 \\
\hline Total & 30 & 12.6777 & 4.11413 & 0.75113 & 11.1415 & 14.2139 & 5.34 & 21.55 \\
\hline
\end{tabular}

\begin{tabular}{|c|c|c|c|c|c|c|}
\hline \multirow{2}{*}{$\begin{array}{c}\text { (I) MATERIAL } \\
\text { (J) MATERIAL }\end{array}$} & Mean Difference & \multicolumn{2}{c|}{ Tukey HSD } & \multicolumn{2}{c|}{ 95\% Confidence Interval } \\
\cline { 3 - 7 } & (I-J) & Std. Error & Sig. & Lower Bound & Upper Bound \\
\hline Sngle Bond & Dentastic & 2.851 & 1.60559 & 0.197 & -1.13 & 6.8319 \\
\hline & Clearfil & -2.4898 & 1.60559 & 0.284 & -6.4707 & 1.4911 \\
\hline Dentastic & Sngle Bond & -2.851 & 1.60559 & 0.197 & -6.8319 & 1.13 \\
\hline & Clearfil & -5.3408 & 1.60559 & 0.007 & -9.3217 & -1.3598 \\
\hline Clearfil & Sngle Bond & 2.4898 & 1.60559 & 0.284 & -1.4911 & 6.4707 \\
\hline & Dentastic & 5.3408 & 1.60559 & 0.007 & 1.3598 & 9.3217 \\
\hline
\end{tabular}

Table 3: Fracture's type in groups.

\begin{tabular}{|c|c|c|c|c|c|}
\hline Fracture /Group & Adhesive & Cohesive in Lime-Lite & Cohesive in Composite & Mixed & Total \\
\hline $\begin{array}{c}\text { ‘DenTASTIC، } \\
\text { CompositeZ250 Lime- Lite }\end{array}$ & 1 & 0 & 0 & 10 \\
\hline $\begin{array}{c}\text { CompositeZ250 } \\
\text { Single bond‘Lime-Lite }\end{array}$ & 2 & 0 & 0 & 8 & 10 \\
\hline
\end{tabular}




\begin{tabular}{|c|l|l|l|l|l|}
\hline Clearfil S3bond‘Lime-Lite & 0 & 0 & 0 & 10 & 10 \\
\hline Total & 3 & 0 & 0 & 27 & 30 \\
\hline
\end{tabular}

The Table 3 shows types of the fractured samples of the used adhesives in segregation. The fractures were much of the type of the mixed type, namely, adhesive and cohesive and no fracture revealed as cohesive in Lime-Lite and composite.

\section{Discussion}

The results extracted out of this research for examining the effects of application of the three types of adhesives Den TASTIC, Single bond, and clearfils ${ }^{3}$ bond on shear bond strength of LimeLite to Z250 composite showed the application of clearfils ${ }^{3}$ bond adhesive was more significant than Den TASTIC recommended by the Lime-Lite Manufacturer however, there is no significant difference revealed with Single bond. Unfortunately, the related field articles and researches under this subject and in particular to Lime-Lite were not much available. Furthermore, there are very few researches in the field of its characteristics; therefore, many semi-related articles reviewed for designing this research and for interpreting the results thereof. In addition, all the due process had investigated in accordance with the ISO 11405 [11].

In the restoration of all-wide cavities with the composite resin, if the gap with the dental pulp is low, it is necessary to use suitable liner and base [1,2]. Nowadays, the more common material used as the liner and base beneath the composite restoration is the light cure glass ionomer that is delivered in the form of powder and liquid, however, the preparation of the mixture with appropriate consistency is counting a difficult work and needs skill and expertness. In the other hand while transferring to cavity, it may contact the walls of the cavities and consequently contaminate the bond surface. In the other hand, due to the powerful bond between Glass ionomer and composite, while etching, the more powerful bond is developing and it is probable that the Glass ionomer may crack $[3,4]$. Approximately two years ago, the USA Pulpdent factory presented a materiel as light cure Liner and Base having the property of Calcium hydroxide along with higher physical and mechanical characteristics. As the manufacturer claimed, LimeLite without adhesive application attached to any composite resin [5]. This matter certainly calls for further future studies, too. It also suggests that, for the improvement of the solidification of the shear bond strength of Lime-Lite to composite, Den TASTIC adhesive, the same product of the above-mentioned company apply.

The results of this research rejected the claim of the manufacturing co. In other words, it means that the suggested adhesive application, it does not carry the shear bond strength, so much, as it claims. The results of the research showed that there was no significant difference statistically between the application of two systems of Single bond and Den TASTIC adhesives. It is perhaps that because both adhesives are having etching stages and so it is probable with the efficacy of solvable and other characteristics of Lime-Lite is the cause of reducing the bond strength between composite and Lime-Lite which is prone to further research. In this research, the clearfils $^{3}$ bond caused the most bond strength between composite and Lime-Lite. This adhesive is a seventh generation self etch that presented in the form of single bottle. This bonding produces in Japan Kuraray Factory Adhesives Group, which has recently been in access. Regarding with the previous research results, the Cearfil Adhesives groups develop the most bond strength with composite, dentin and enamel. Furthermore, Clearfil liner2v was selected as the best self etch adhesive last year. Thus, the older generation of this material is having a lot of proven advantages and properties [15-18]. It seems that being self etch does not have any negative efficacy on the bond strength of LimeLite to composite but other factors are effective. The survey of Banava and her colleagues have investigated the effect of several adhesive on the compressive strength of Lime-Lite and Calcium hydroxide is the donator of the positive effect of self etch adhesive comparing with Total etch adhesive [6]. In clearfils $^{3}$ bond adhesive, the existing monomer is MDP (10 Meta Keriloloxydil dehydrogen phosphate) which has more than 20 years of successful experience among the existing adhesive monomers. The specified molecular structure of this monomer causes adhesive to decalcify the tooth tissue simultaneously, permeates in it, and develops chemical bond with the calcium ions and Hydroxyapatite.

It seems that the same characteristic causes the bond strength of the composite and Lime-Lite in this research compared to other adhesives upper because this adhesive has had the ability of attaching to the existing Hydroxyapatite in Lime-Lite, In the other hand the chemical bond resulting from existing MDP, resistant against hydrolyze. Therefore, clearfils $^{3}$ bond adhesive is less under the influence of hydrolyzes resulting from the saliva in enamel and pulp liquid in dentin [5]. On the other hand, the modern technology the molecular diffusion "Molecular Dispersion Technology" in preparation this adhesive has caused that this materiel without needing to shake the bottle and mixing it concerning other self etch adhesives available is necessary; the bonding abilities and can act as multipurpose systems and surely with easier quicker application and less technical sensitivity [5]. The lack of the significant difference between application of this mentioned adhesive and Z250 Composite which both of them are from the same factory or it is possible that due to the similar available compositions in both single bond and clearfils ${ }^{3}$ bond. The fracture type in the Lime-Lite groups are only $10 \%$ of the cases in the form of adhesive and in $90 \%$ of cases are as the combined (adhesive, codhesive) which is the indicator of the material interference and the used adhesives. Regarding the obtained results of the present research both researchers' assumptions are rejected; namely the adhesive application an effect on the shear bond strength of LimeLite to composite and most fractures are of the cohesive type. 


\section{Conclusion}

a) The adhesive application and the adhesive types have impacts on shear bond strength of Lime-Lite to composite.

b) Shear bond strength of Lime-Lite to composite were obtained from the most to the least, respectively: bond > Single bond $>$ Den TASTIC

c) There were no statistical differences between shear bond strength of Lime-Lite to composite with Dent TASTIC application and Single bond and between bond and Single bond.

\section{Acknowledgement}

Hereby we would like to appreciate a lot and much to thank Dr. Alizadeh the professor of Tehran Amirkabir University-Mechanic Engineering Faculty for assisting us in the biomechanics portions of the project.

We thank also Eng. Mr. bass Ostadzadeh due to his helpful collaboration in guiding us to perform this Project. In addition, special thanks to Dr. KharaziFard who counseled us on the statistical points of the project.

\section{References}

1. Roberson TM, Heymann H, Swift EJ (2002) Sturdevant's Art \& Science of Operative Dentistry ( $4^{\text {th }}$ edn), Mosby, USA, pp. 104, 127-130, 133134, 142, 148, 154, 157, 337-338, 341.

2. Craig RG, Powers JM (2006) Restorative dental materials (11 ${ }^{\text {th }}$ edn), chapter 20, Mosby, USA.

3. Summit JB, Robbinson W, Schwartz R (2001) Operative dentistry (1 $1^{\text {st }}$ edn), Quintessence, China, pp. 94, 96, 103, 219-224.

4. Noort RV (2002) Dental materials ( $\left.2^{\text {nd }} e d n\right)$, Mosby, Hong Kong, pp. 134, 137-138, 141-143, 145.

5. http://www.pulpdent.com/Lime-Lite.html/last updated 2008.
6. Banava S, Zinsaz Boroojerdy S (2007) The effect of Single bond and Prompt L-Pop on compressive strength of Calcium hydroxide and Lime-Lite (in vitro). Tehran Azad University, Iran.

7. Rosen M, Cohen J, Becker PJ (1991) Bond strength of glass ionomer cement to composite resin. JDent Assoc S Afr 46(10): 511-513.

8. Mongkolnam P, Tyas M J (1994) Light cured lining materials: A laboratory study. Dent mater 10(3): 196-202.

9. Farah CS, Orton VG, Collard SM (1998) Shear bond strength of chemical and light-cured glass ionomer cements bonded to resin composites. Aust Dent j 43(2): 81-86.

10. Knight GM, McIntyre JM, Mulyani (2006) Bond strengths between composite resin and auto cure glass ionomer cement using the co-cure technique. Aust Dent j 51(2): 175-179.

11. International Organization for Standardization, ISO 11405, 1994$12-15$, Dental materials- Guidance on testing of adhesion to tooth structure.

12. Das UM, G S (2009) Bonding agents in pit and fissure sealants: a review. Int J Clin Pediatr Dent 2(3):1-6.

13. http://www.Dentsply.com/cosmetic dentistry/Esthetix/last updated 2008

14. http://www.kuraraydental.com/dental adhesive/Clearfil S3bond/last updated 2008

15. Ishikawa A, Shimada Y, Foxton RM, Tagami J (2007) Micro-tensile and micro-shear bond strengths of current self-etch adhesives to enamel and dentin. Am J Dent 20(3): 161-166.

16. Imamiya C, Shimada Y, Burrow MF, Tagami J (2007) Shear bond characteristics of a tooth-colored temporary coating material to enamel. Am J Dent 20(3): 177-181.

17. Shimada Y, Senawongse P, Harnirattisai C, Burrow MF, Nakaoki Y, et al. (2002) bond strength of two adhesive systems to primary and permanent enamel .Oper dent 27(4): 403-409.

18. Shimada Y, Iwamoto N, Kawashima M, Burrow MF, Tagami J (2003) Shear bond strength of current adhesive systems to enamel, Dentin and dentin-enamel junction region. Oper dent 28(5): 585-590.

\section{Your next submission with Juniper Publishers} will reach you the below assets

- Quality Editorial service

- Swift Peer Review

- Reprints availability

- E-prints Service

- Manuscript Podcast for convenient understanding

- Global attainment for your research

- Manuscript accessibility in different formats

( Pdf, E-pub, Full Text, Audio)

- Unceasing customer service

Track the below URL for one-step submission https://juniperpublishers.com/online-submission.php 